\title{
A aula no contexto histórico global: pensamentos e reflexões
}

\section{The class in the global historical context: thoughts and reflexions}

Ana Angelica da Silva ${ }^{1}$ Carlos Eduardo Prata Antunes ${ }^{2}$ Janaina Neri Vargas Gonçalves ${ }^{3}$ Tatiana Serpa Guimarães Passagli ${ }^{4}$

1 Mestranda do curso de Pós-Graduação em Psicologia do UniCEUB. Graduada em Pedagogia por ICSH e Especialista em Docência Superior pela FATED.

2 Mestrando do curso de Pós-Graduação em Psicologia do UniCEUB. Pós-Graduado em Atividade de Polícia Judiciária (Academia de Polícia Civil do Distrito Federal e Faculdades FORTIUM) e especialista em Educação pela UNEB. Graduado em Psicologia e Ciências Contábeis pelo UniCEUB e em Teologia pela Faculdade de Cristo de Brasília - FTCB.

3 Mestranda do curso de Pós-Graduação em Psicologia do UniCEUB. Graduada em Psicologia pelo UniCEUB.

4 Mestranda do curso de Pós-Graduação em Psicologia do UniCEUB. Especialista em Docência Superior por IESB e Graduada em Pedadogia pelo IESB. 


\section{Introdução}

O presente artigo surge a partir das aulas vivenciadas pelos autores, a partir de sua experiência pedagógica e com base nos textos estudados no decorrer dos cursos de docência superior ministrados pela Dra. Ilma Passos Alencastro Veiga, no âmbito da Pós Graduação Stricto Sensu, Mestrado em Psicologia do Centro Universitário de Brasília - UniCEUB.

O trabalho tem como objetivo reconceitualizar a aula no contexto histórico global, bem como defini-la de acordo com as perspectivas pedagógicas contemporâneas.

\section{Um breve histórico da aula no Brasil}

O conceito de "aula", no contexto brasileiro, tem sua origem no modelo europeu de educação. De acordo com Silva (2010), até a Idade Média não existia um ambiente como conhecemos hoje destinado à "aula". O ideário do que conhecemos como "aula" foi amadurecendo à medida que os métodos pedagógicos foram sendo desenvolvidos e aplicados no processo educacional, observando naturalmente as exigências estabelecidas pelo discurso vigente, bem como a política estatal voltadas para esse segmento.

Partindo desses princípios, serão observados, em momentos históricos distintos, a evolução do processo educativo e suas influências delimitadoras.

Segundo Silva (2010), algumas ordens protestantes, no século XVI, na tentativa de desvincular-se do domínio católico, incentivaram a educação como meio de se conhecer a verdade bíblica. Entre essas ordens, o calvinismo defendia a criação de uma comunidade que valorizava a disciplina como elementos fundantes da escola.

A igreja católica também apostou na educação como meio de evangelização dos "gentios" e criou, ainda na Idade Média, a ordem dos jesuítas. Esses religiosos chegaram ao Brasil por volta de 1549 e fundaram escolas e seminários em diversas regiões do país. O ensino proporcionado por eles se baseava na reprodução dos valores dos colonizadores europeus, bem como na catequese dos "gentios", conforme afirma Silva (2010):

A catequização era revestida de um caráter pedagógico, vista como alternativa de conversão pelo convencimento por meio de práticas pedagógicas institucionais que enfatizavam a leitura, a escrita e o cálculo. (SILVA, 2010, p. 19)
Na verdade, a aula jesuíta enfatizava a individualidade, isto é, o professor se reportava ao aluno e o método era o interrogatório, no qual o aluno deveria ter o conteúdo estudado, decorado e naturalmente reproduzido. Os professores estimulavam a competição entre os alunos com o objetivo de favorecer o aprendizado. Segundo Silva (2010), a avaliação era realizada diariamente e levava em consideração o desenvolvimento, o interesse do aluno, bem como a competição entre os alunos. Além disso, de acordo Aranha (1989), era dado destaque elitista à educação, que visava à classe de dirigentes e ao grau acadêmico para estratificação social. Por essa razão, os mestiços foram retirados do ambiente escolar por serem consideradas pessoas arruaceiras e mal adaptadas a esse ambiente, reforçando assim a discriminação social entre os discentes. Isso remonta um ideário Foucaultiano do discurso de poder, em que a manutenção de determinada ordem social impõe-se sobre o destino dos sujeitos:

[...] Portanto, os saberes dominados são esses blocos de saber histórico que estavam presentes e mascarados no interior dos conjuntos funcionais e sistemáticos e que a crítica pode fazer aparecer, evidentemente, através dos instrumentos da erudição. (FOUCAULT, 1996, p. 170).

Devido a atritos com funcionários da coroa e ao acúmulo de riqueza por parte dos religiosos, os jesuítas foram expulsos do país em 1759 pelo Marquês de Pombal. No entanto, não existiu uma mudança pedagógica importante de imediato. O que ocorreu foi uma reestruturação administrativa. De acordo com Silva (2010), a ideia do Marquês era mudar o foco da educação, que deixava de servir aos interesses religiosos e passava a servir aos interesses do Estado, defendendo-os. Dessa forma, a reforma promovida pelo Marquês de Pombal introduziu o ensino laico e público e permitiu a entrada das ciências experimentais no ensino, tornando-o mais prático e utilitário. Para tanto, os cursos seriados dos jesuítas foram substituídos pela "aula régia", que preparava as elites para complementar os seus estudos na Europa. A metodologia dessa aula baseava-se em aulas avulsas, ministradas por docentes improvisados e sem formação acadêmica. A "aula régia" não vingou devido a dificuldades por partes dos professores em assimilar a nova maneira de educar estabelecida pelo Marquês.

Destaca-se que na reforma pombalina surgiram diversos cursos superiores e também cursos técnicos com intuito de atender às demandas de Portugal. Porém, o 
ensino elementar era quase inexistente e era ministrado em lugares inapropriados. A preocupação com o ensino primário iniciou-se a partir da segunda década do século XIX. No entanto, essa preocupação se limitava ainda a uma espécie de generalização educacional que se voltava apenas para a leitura, a escrita e o saber fazer contas. Esse modo de ver a educação tinha uma intenção política numa tentativa de garantir a governabilidade e de criar um projeto de país independente. (SILVA, 2010).

Conforme Silva (2010), a instituição escola foi lentamente tornando-se importante para o corpo social, sendo que as necessidades de articular novos conhecimentos também foram sendo introduzidas nos currículos, a ponto de substituir a "escola de primeiras letras" pela "instrução elementar". Foram inseridos nas aulas materiais pedagógicos tais como: globos, mapas, figuras, laboratórios, mobília especial (em substituição aos bancos sem encosto). O quadro-negro ganhou espaço como importante recurso didático desse período.

Entretanto, de acordo com Silva (2010), os métodos de ensino ainda não tinham sido discutidos até 1870, ou pior, as discussões estavam atreladas apenas à organização da classe e aos tempos escolares, e não à forma de ensinar. A partir da introdução do método intuitivo, criado nos Estados Unidos e na Inglaterra em 1880, ocorreram mudanças significativas no processo de aprendizagem. Esse método enfatizava a intuição e a observação como momentos de aprendizagem e respeitava os ritmos de aprendizagem de cada aluno. Além disso, privilegiava a aprendizagem por meio da ilustração e do desenho, o que tornou a "figura" tão significativa quanto o texto no livro didático. Essa nova perspectiva metodológica provocou discussões sobre a profissionalização do magistério e sobre o método como caminho orientador dos processos educativos. Apontou ainda para uma otimização dos processos, ou seja, para a seriação, para uniformização dos conteúdos estruturados por método, para a organização do tempo escolar e para a distribuição gradativa dos conteúdos em um determinado período de tempo.

\section{Realidade da aula no Brasil contemporâneo}

A realidade brasileira do século XX era a de um ensino tradicional do ponto de vista dos métodos e politicamente conservadora, o que não atendia às demandas educacionais. Silva (2010) destaca que o modelo brasileiro era intelectualista, autoritário e conservador. Nesse contexto, surgiu a Escola Nova, reagindo contra as tendências passivas e verbalistas da escola tradicional, escola essa que não observava as capacidades individuais de cada sujeito. Para os escolanovistas, a escola precisava oferecer à criança condições de serem inseridas socialmente por meio de atividades em grupo. De acordo com Libâneo (1993, p. 66):

Os adeptos da Escola Nova costumam dizer que o professor não ensina; antes, ajuda o aluno a aprender. Ou seja, a didática não é a direção do ensino, é a orientação da aprendizagem, uma vez que esta é uma experiência própria do aluno por meio da pesquisa da investigação.

Para Silva (2010), apesar de as idéias da Escola Nova terem sido defendidas pelos docentes, os seus ideais não se tornaram senso comum no meio educacional, apenas algumas de suas práticas foram adotadas (ainda no século XXI).

Aranha (1989) também trata da Escola Novista. Para ela, essa corrente supera o modelo tradicional de ensino uma vez que, ao valorizar os jogos, os exercícios físicos, as práticas de desenvolvimento de motricidade e a percepção para estímulos de habilidades, buscava a compreensão da natureza psicológica da criança, estimulando a espontaneidade, bem como a introdução da educação inclusiva.

Na década de 1960, o Brasil passava por um período desenvolvimentista, em que o país buscava qualificação da mão de obra para fomentar o aumento da produção. Segundo Silva (2010, p. 33), “(...) a tecnologia educacional surge como meio de garantir a racionalização dos processos de trabalho e, em decorrência, sua eficiência e eficácia." Devido a isso, algumas mudanças educacionais foram reflexos desse ideário tecnicista:

Aula tecnicista é invadida por materiais de instrução programada e instrução modelar, técnicas e recursos audiovisuais e forte utilização do livro didático, enfatizando a tendência de reprodução da realidade por modelos predefinidos, fortalecendo a ideologia política do momento. Há também a utilização dos multimeios para educação de massa, nos moldes no ensino supletivo e da teleducação, e a avaliação escolar como função somativa [...] (SILVA, 2010, p. 34).

Desse modo, a aula se tornou uma linha em série em que os sujeitos envolvidos no processo educacional simplesmente reproduziam o conteúdo e tentavam utilizá-lo diretamente no cotidiano alienador do trabalho. 
Na contramão do ensino tecnicista, Freire (2011) sugere que a prática docente deve ser crítica, dinâmica e dialética entre o fazer e o pensar sobre o fazer. Em outras palavras, em vez do pensamento pronto e acabado, a reflexão crítica é apresentada como forma de aprendizagem.

Em 1979 inicia-se uma discussão influenciada pela pedagogia histórica-crítica, que pensava o processo de aprendizagem de maneira diferente dos escolanovistas e dos tecnicistas. Para Silva (2010), os pensadores histórico-críticos enfatizavam a relação entre professor e aluno, ou seja, o ato de "fazer aula" tinha como prerrogativa uma atuação mais efetiva do professor no sentido de pensar o seu trabalho definindo objetivos, conteúdos, metodologias e estratégias de avaliação. Isso precisava ser pensado principalmente porque a relação entre professor e aluno era negligenciada, no sentido da não-observação dos contextos complexos e multifacetados que norteiam as sociedades. Para tanto, fez-se necessário relacionar o conteúdo erudito com a cultura popular para que pudesse ocorrer uma participação crítica maior por parte dos discentes.

Atualmente estamos vivendo de maneira exacerbada a ênfase no indivíduo e na globalização. Nessa realidade, tem sido exigida do professor a capacidade de manipular as tecnologias no contexto escolar. A esse respeito, Silva (2010) argumenta que a inserção de tais recursos precisa ser vista com muito cuidado, pois pode significar um retrocesso em relação ao método tradicional, em que o aluno se torna passivo ou simplesmente um receptor de informações. O professor precisa entender que o seu papel é o de educador:

É preciso que o professor reconheça o seu importante papel como agente promotor do processo de aprendizagem do aluno, construtor do conhecimento, e crie condições para que este se sinta desafiado, motivado a explorar, refletir e rever idéias, conceitos e teorias, planejando suas aulas com o auxílio das novas tecnologias ou não, com clareza em relação à maneira de articular os componentes do processo de ensino. (SILVA, 2010, p. 36).

Assim, como propõe Libâneo (1993, p. 53), o ensino deve contribuir para "desenvolver conhecimentos, capacidades e qualidades para o exercício autônomo, consciente e crítico da cidadania”. É importante a escola conhecer o contexto social que o aluno está inserido com o objetivo de propor ações que atendam às expectativas da comunidade escolar.

\section{Um outro ponto de partida para se entender aula}

Com base nas ideias dos autores mencionados nas seções anteriores e no que propõe Veiga (1992, p. 117), concluímos que a

sala de aula é parte de um todo, está inserida numa instituição educativa, que por sua vez, está filiada a um sistema educacional, que também é parte de um sistema sócio-econômico, político e cultural mais amplo.

Sendo assim, para compor esse ambiente, a aula é um espaço de reflexão e de relações interpessoais e afetivas baseado no conhecimento mútuo, cuja base é tripla: o aprender, a aprender, à aprender.

A aula é um espaço de reflexão no momento em que as ideias do senso comum, unidas ao conhecimento científico, propiciam a oportunidade para novos conhecimentos, conhecimentos esses que estão inseridos nas relações interpessoais (afetivas, sociais, políticas, econômicas e culturais), proporcionando assim a diversidade do conhecimento global.

O primeiro aprender baseia-se no fato que o ser humano não é simplesmente uma máquina em que são depositadas informações, ou seja, o ser humano não chega ao ambiente escolar desprovido de conhecimento senso comum, princípios éticos e morais.

O segundo aprender está voltado para o ambiente onde acontecem as relações sociais, cognitivas e afetivas, para a construção do novo aprender.

O terceiro aprender é usar dos outros dois aprenderes para um novo aprender; o "aprender, a aprender", é um ciclo que se retroalimenta entre sujeitos que aprendem. Esse aprender envolve aspectos subjetivos da personalidade, que se produz em contextos e situações concretas com a articulação entre o sujeito e seu contexto vivencial, numa ação integralmente inovadora.

\section{Algumas palavras finais}

A ideia de aula precisa ser entendida como um processo que atravessa gerações e que é influenciado pelo discurso vigente. No entanto, faz-se necessário avançar em muitos momentos os discursos e entender que o processo de se "fazer aula" deve privilegiar:

a) a interação dos sujeitos; 
b) proporcionar a aproximação do saber técnico com a experiência dos alunos - tema mencionado por Vygotsky (1987), que propunha uma diminuição da distância entre o desenvolvimento atual na resolução de problemas e o nível de desenvolvimento potencial determinado pela resolução de problemas sob orientação de um parceiro mais capacitado e experiente;

c) o momento histórico em que vivemos e a capacidade de refletir sobre ele, à medida que as visões são desnudadas e conseguimos ver o que anteriormente não víamos;

d) o uso de tecnologias como auxiliares (apensos) ao processo criativo, não como fim e único objeto para aprendizagem - de acordo com as palavras de Kensi (2009), os processos de ensino sempre dependem mais dos sujeitos envolvidos no processo do que das tecnologias compartilhadas na relação educacional e

e) o planejamento, que, para além de funções burocráticas, precisa servir como orientador de práticas, no intuito de melhorar aproveitamento do conteúdo e consequentemente melhorar o processo educativo (SEVERINO, 2009).

\section{Referências}

AMORIM, Verussi Melo; CASTANHO, Maria Eugênia. Da dimensão estética da aula ou do lugar da beleza na educação. In: VEIGA, I. P. A. (Org.). Aula: gênese, dimensões, princípios e práticas. 2. ed. Campinas: Papirus, 2010. p. 95-111.

ARANHA, Maria Lúcia de Arruda. História da educação. São Paulo: Moderna, 1989.
FERNANDES, Cleoni Maria Barboza. À procura da senha da vida - de-senha a aula dialógica? In: VEIGA, I. P. A. (Org.). Aula: gênese, dimensões, princípios e práticas. 2. ed. Campinas: Papirus, 2010. p. 145-165.

FOUCAULT, Michel. Microfísica do poder. 12. ed. Rio de Janeiro: Graal, 1996.

FREIRE, Paulo. Pedagogia da autonomia: saberes necessários à prática educativa. São Paulo: Paz e Terra, 2011.

KENSKI, Vani Moreira. Novos processos de interação e comunicação no ensino mediado pelas tecnologias. In: PIMENTA, S. G.; ALMEIDA, M. I. Pedagogia universitária. São Paulo: EDUSP, 2009. p.237-249.

LIBÂNEO, José Carlos. Didática. São Paulo: Cortez, 1993.

MARTINEZ, Albertina Mitijáns. A criatividade como princípio funcional da aula: limites e possibilidades. In: VEIGA, I. P. A. (Org.). Aula: gênese, dimensões, princípios e práticas. 2. ed. Campinas: Papirus, 2010. p. 115-143.

RIOS, Terezinha Azerêdo. A dimensão ética da aula ou que fazemos com eles. In: VEIGA, I. P. A. (Org.). Aula: gênese, dimensões, princípios e práticas. 2. ed. Campinas: Papirus, 2010. p. 73-93.

SILVA, Edileuza Fernandes. A aula no contexto histórico. In: VEIGA, I. P. A. (Org.). Aula: gênese, dimensões, princípios e práticas. 2. ed. Campinas: Papirus, 2010. p.15-42.

SEVERINO, Antonio Joaquim. Ensino e pesquisa na docência universitária: caminhos para integração. In: PIMENTA, S. G.; ALMEIDA, M. I. Pedagogia universitária. São Paulo: EDUSP, 2009. p.129-146.

VEIGA, Ilma Passos Alencastro. A prática pedagógica do professor de didática. Campinas: Papirus, 1992.

VYGOTSKY, L. S. Thinking and speech. In: RIEBER, R. W.; CARTON, A. S. (Ed.). The collected works of L. S. Vygotsky: problems of general psychology. New York: Plenum Press, 1987. p.39-285. 


\section{Para publicar na revista}

Universitas Humanas,

acesse $o$ endereço eletrônico www.publicacoesacademicas.uniceub.br. Observe as normas de publicação, para facilitar e agilizar o trabalho de edição. 